* Doutor em Direito pela Pontifícia Universidade Católica de São Paulo (PUC/ $\mathrm{SP})$. Mestre em Direito pela Pontifícia Universidade Católica de São Paulo (PUC/SP). Especialista em Processo Civil pela Pontifícia Universidade Católica de São Paulo (PUC/SP). Email: contatoapb@protonmail.com

* Mestrando em Direito Processual pela Universidade Federal do Espírito Santo (UFES). Especialista em Direito Processual Civil pelo Damásio Educacional (DAMASIO) Graduado em Direito pela Universidade Vila Velha (UVV). Graduado em Ciências Biológicas pela Universidade Federal do Espírito Santo (UFES). Email: tvilarinho@gmail.com

\section{NEgóCIOS JURÍDICOS PROCESSUAIS ATÍPICOS EM CONTRATOS INTEREMPRESARIAIS E A PANDEMIA DA COVID 19}

\author{
ATYPICAL PROCEDURAL NEGOTIATION OF INTERCOMPANY \\ CONTRACTS AND THE COVID 19 PANDEMIC
}

\section{Augusto Passamani Bufulin* Tiago Aguiar Vilarinho**}

Como citar: BUFULIN, Augusto Passamani. VILARINHO, Tiago Aguiar. Negócios jurídicos processuais atípicos em contratos interempresariais e a pandemia da covid 19. Scientia Iuris, Londrina, v. 24, n. 3, p. 10-30, nov. 2020. DOI: 10.5433/2178-8189.2020v24n3p10. ISSN: 2178-8189.

Resumo: A pesquisa investiga a pandemia da COVID-19 e seus efeitos sobre as relações jurídicas como campo fértil para a valorização da renegociação nas relações jurídicas em geral e, de maneira mais específica, se o momento representa oportunidade para que se estimule a negociação processual atípica nos contratos interempresariais, de maneira a que, em havendo evolução da contenda para a esfera judicial, a causa seja solucionada em condições melhor ajustadas às características essenciais destas transações e das circunstâncias ora vigentes. Apoiase em raciocínio hipotético-dedutivo com divisão do trabalho em três seções nucleares, iniciando-se na contextualização dos efeitos da pandemia como ensejadores de um maior quadro de negociabilidade não apenas material, mas também com efeitos processuais. Caracterizam-se os contratos interempresariais e suas notas distintivas, de maneira a melhor compreender a amplitude negocial que lhes é ínsita, para que se analise, enfim, as hipóteses de negócios jurídicos processuais pertinentes às transações entre empresas no atual cenário.

Palavras-chave: Pandemia COVID-19. Autorregramento da Vontade. Negócios Jurídicos Processuais Atípicos. Contratos Interempresariais.

\begin{abstract}
This research investigates the COVID-19 pandemic and its effects on legal acts. This paper questions whether it is a justifiable reason for renegotiating legal transactions and investigates if current events represent an opportunity for more atypical procedural negotiations in intercompany contracts, so
\end{abstract}


that, in the event that the dispute evolves to adjudication, the case would be resolved in conditions better adjusted to the essential characteristics of these types of transactions and the circumstances of the moment. This study uses the hypothetical-deductive method and divides itself into three core sections, starting with a general analysis of the effects of the pandemic as a means for negotiation, not only material, but also procedural. Furthermore, intercompany contracts and their distinctive characteristics are explored to better understand their range of transactions and the hypotheses of procedural acts pertinent to legal transactions in the current scenario.

Keywords: Pandemic COVID-19. Self-regulation. Atypical Legal Proceedings. Intercompany Contracts. 


\section{INTRODUÇÃO}

A presente investigação se concentra na análise da pandemia da COVID-19 como fator de estímulo à renegociação contratual diante do quadro de relativa insegurança jurídica e de crise de adimplemento instaurado e, nesse contexto, busca responder se no ensejo das aludidas repactuações seria oportuno, no âmbito dos contratos interempresariais, o exercício do poder de autorregramento da vontade para a estipulação de cláusulas destinadas a produzir efeitos em eventual processo judicial, objetivando tornar o procedimento melhor ajustado às especificidades do ramo e às circunstâncias ora vigentes.

Objetiva-se, também, identificação de hipóteses de negociação processual que se apresentem como profícuas na seara das transações interempresariais em curso ou que venham a se estabelecer enquanto vigentes os efeitos da pandemia do novo Coronavírus, tendo como norte as características inerentes aos contratos celebrados entre partes empresárias.

A análise das questões-problema suscitadas de justifica em função das adversidades decorrentes da pandemia da COVID-19, entre as quais se observa a potencial judicialização das relações jurídicas em geral e, no que toca ao presente trabalho, das transações entre partes empresárias, que normalmente envolvem a circulação de bens de expressivo valor econômico. Nesse viés, a identificação de ajustes procedimentais úteis à transformação de eventual - talvez até inevitável - processo judicial o mais efetivo possível é tarefa que se amolda às necessidades ora vigentes.

Ampara-se no método hipotético-dedutivo, partindo-se das premissas acima delineadas para a verificação das hipóteses particulares de viabilidade de negócios jurídicos processuais identificados como pertinentes aos contratos interempresariais.

Para alcance dos objetivos propostos, divide-se a pesquisa em três partes nucleares, iniciando-se com a verificação dos efeitos do novo Coronavírus nas relações jurídicas e a oportunidade renegociação se valendo de negócios jurídicos que venham a produzir efeitos no processo, caso a lide não logre ser solucionada pré-processualmente. Para tanto, situa-se a negociação processual atípica como decorrência do exercício do autorregramento da vontade no processo e se tangencia a ainda árida questão referente aos limites objetivos dessas convenções.

Em seguida, passa-se à caracterização dos contratos interempresariais e as implicações das notas distintivas identificadas no grau de autonomia para a disposição de situações jurídicas e alteração procedimental atribuído a negócios desta natureza.

Enfim, passa-se à aferição de hipóteses de aplicabilidade da negociação processual atípica em contratos interempresariais consideradas possíveis e úteis para a condução de eventuais demandas em condições menos adversas, dada as já abundantes dificuldades que a pandemia da COVID-19 impõe. 


\section{EFEITOS DA PANDEMIA DA COVID-19 NAS RELAÇÕES CONTRATUAIS: A OPORTUNIDADE DE RENEGOCIAÇÃO COM PRESTÍGIO À CELEBRAÇÃO DE NEGÓCIOS JURÍDICOS PROCESSUAIS ATÍPICOS}

Com a rápida disseminação geográfica do novo Coronavírus (SARS-COV-2) e diante do aumento exponencial do número de novos casos diários de contaminação, a Organização Mundial de Saúde declarou, em 11 de março de 2020, a caracterização da COVID-19 (enfermidade causada pelo SARS-COV-2) como pandemia (World Health Organization, 2020). Instaurou-se, então, verdadeiro quadro de calamidade pública, tendo diversos países passado a adotar, ainda que com diferentes intensidades, medidas de contenção do contágio pela COVID-19, entre elas o distanciamento social, o fechamento do comércio e das instituições de ensino, assim como a paralisação dos serviços públicos e privados não essenciais.

Diante desse cenário, as relações jurídicas de direito privado, em especial as contratuais, passaram a sofrer fortes impactos em seu regular desenvolvimento, não apenas pelos efeitos diretos da necessidade de afastamento social, mas também em função das consequências econômicofinanceiras decorrentes da estagnação da circulação de bens e serviços. Os impactos da pandemia sobre o desenvolvimento das relações jurídicas têm sido apontados, nos estudos iniciais sobre o tema, ${ }^{1}$ como eventos de força maior, assim considerados, nos termos do parágrafo único do art. 393 do Código Civil, aqueles que se constituam no fato necessário, cujos efeitos não era possível evitar ou impedir.

No âmbito das relações contratuais vige o princípio da força obrigatória do contrato - pacta sunt servanda -, que constrange as partes ao cumprimento do que restar estipulado nas avenças (TARTUCE, 2014). ${ }^{2}$ Nada obstante, referido princípio pode sofrer mitigação diante de situações supervenientes imprevisíveis que venham a desequilibrar as prestações pactuadas, ensejando a revisão contratual, tendo como bússola a manutenção do contrato, vez que a sua resolução deve ser a ultima ratio (TARTUCE, 2014).

Essa possibilidade de revisão é decorrência da teoria da imprevisão, de origem francesa, cuja essência se vislumbra nos arts. 317 e 478 do Código Civil de 2002, ${ }^{3}$ dispositivos de aplicação já bastante consolidada em demandas judiciais de revisão ou resolução contratual por fato superveniente. Em que pese a possibilidade de revisão de determinadas relações contratuais, nem sempre o contexto fático das situações impactadas pela da pandemia de COVID-19 permitirá que se solucione satisfatoriamente a contenda a partir da Teoria da Imprevisão ou de outras hipóteses revisionais, a exemplo das que bem anotam Nelson Nery Jr. e Rosa Maria de Andrade Nery (2019,

1 Neste sentido, cf. Cláudia Lima Marques (2020, p. 11): “Conclua-se pela existência da exceção dilatória, por força da boa-fé, em nosso sistema privado e no direito do consumidor, assim como em ser esta situação excepcional da Pandemia do COVID-19, uma força maior, que pode excepcionar conforme o a figura da mora debitoris".

2 No mesmo sentido, Gustavo Tepedino (2011, p. 338): “Como é cediço, o contrato é obrigatório e vinculante entre as partes, daí decorrendo a intangibilidade de seu conteúdo. $\mathrm{Na}$ espécie, uma vez efetuada a proposta por X, sua aceitação pelos vendedores fez nascer relação contratual plenamente válida e eficaz e, por isso mesmo, vinculante".

3 Não se olvida da existência de divergência acerca da teoria adotada pelo Código Civil de 2002, no que atine à revisão contratual por fato superveniente. Segundo Flávio Tartuce (2014), parcela da doutrina se ampara na redação do art. 317 para afirmar a adoção da Teoria da Imprevisão. De outro turno, há construções doutrinárias no sentido de que o art. 478 do CC/2002, de redação inspirada no art. 1467 do Código Civil Italiano, teria adotado a Teoria da Onerosidade Excessiva. 
p. 724): “a) quebra da base objetiva do negócio; b) desequilíbrio contratual; c) desproporção da prestação; d) quebra da função social do contrato; e) ofensa à boa-fé objetiva etc". Tal constatação levou, inclusive, o Congresso Nacional a editar de Projeto de Lei para instituir Regime Jurídico Emergencial e Transitório de Direito Privado. ${ }^{4}$

Ao cenário de crise de adimplemento nas relações contratuais, soma-se, então, o quadro de conflito de certeza jurídica quanto ao regime legal aplicável às avenças, afetando sobremaneira a cláusula da segurança jurídica, corolária do Estado de Direito, valor que exprime a confiança do indivíduo no império da lei e na garantia da justiça, como bem salienta Couture (1958, p. 146): "Si el individuo no tuviera la seguridad de que existe en el orden del derecho un instrumento idóneo para darle la razón cuando la tiene y hacerle justicia cuando le falta, su fe en el derecho habría desaparecido".

Nesse momento, é natural que haja divergência de posições assumidas pelas partes acerca da norma legal a incidir sobre a relação contratual ou daquilo que seja a solução mais equânime para a manutenção da avença e de seu equilíbrio, potencializando a judicialização da controvérsia. ${ }^{5}$

O contexto nos permite afirmar que a renegociação ganhará destaque no âmbito das relações privadas em geral e, em especial, nos contratos. Decerto as empresas, tanto nas relações contratuais formuladas entre si em ambiente regulado precipuamente pelo Código Civil - contratos interempresariais, objeto do presente estudo - quanto nos negócios de natureza consumerista, se colocarão diante de situações em que os instrumentos negociais deverão ser reavaliados para que deles se extraiam soluções aptas a restabelecer o sinalagma tal qual verificado no momento da celebração.

Assim, no ensejo da revisitação do contratos interempresariais, o que, diante dos efeitos da pandemia, se mostra essencial para que o objeto negocial não se frustre por completo, ${ }^{6}$ é possível a celebração de ajustes de vontade destinados a produzir efeitos em ambiente processual, oportunizando a resolução de eventual controvérsia de maneira otimizada, por meio de um procedimento melhor ajustado às especificidades da situação material. É o que se investiga com maior detalhamento nas linhas seguintes.

4 Trata-se do Projeto de Lei $n^{\circ} 1179 / 2020$, de iniciativa do Senado Federal, aprovado em 10 de junho de 2020, materializando-se na Lei $\mathrm{n}^{\circ} 14.010 / 2020$. Em síntese, o projeto se ancorava em premissas tais como: I) o estabelecimento de uma cisão de tratamento entre as relações civis paritárias (direito civil e comercial) e as relações assimétricas (direito do consumidor e das relações locatícias) e II) não derrogação da legislação vigente atinente à matéria, estabelecendo apenas mecanismos de temperamento ou suspensão temporária da aplicação de determinadas regras durante o RJET. Nada obstante, os dispositivos que tratavam da modulação das relações jurídicas civis foram vetados, sob a justificativa de que os mecanismos hoje existentes, como as teorias da imprevisão e a onerosidade excessiva, são suficientes para o escopo de regulação transitória.

$5 \mathrm{O}$ quadro de incerteza jurídica tende a se projetar para a esfera decisória das demandas relacionadas à pandemia da COVID-19, impulsionando a discricionariedade judicial que, segundo Ronald Dworkin (2007), é aceita pelos adeptos do positivismo jurídico nos chamados "casos difíceis", como decorrência da ausência de perfeita subsunção do fato à norma.

6 Não apenas essencial, mas, altamente recomendável diante do atual cenário. Anderson Schreiber (2018) defende que ao se identificar o desequilíbrio contratual as partes devem prontamente reavaliar o negócio para superar a onerosidade excessiva, como parte do que denomina dever de renegociação, que decorre da boa-fé objetiva e integra o contrato independentemente de previsão. 


\subsection{Autorregramento da vontade no peso}

Como visto, o conturbado momento induz a uma valorização dos mecanismos de repactuação contratual (negociação) ${ }^{7}$, para que a solução de eventuais impasses seja construída consensualmente, ou seja, com contornos definidos pelas próprias partes da relação material. No entanto, verifica-se potencial, também, para uma reconfiguração do contrato com a previsão de cláusulas destinadas a imprimir a maior efetividade possível na solução jurisdicional da contenda, caso não haja consenso sobre parcela do objeto negocial. Nessa perspectiva de repactuação, que exige cautela das partes celebrantes, inclusive no que se refere a um tratamento específico e adequado de futura demanda judicial, ganha relevo a possibilidade de autorregramento da vontade com efeitos processuais. Trata-se da utilização dos negócios jurídicos processuais, passíveis de celebração de maneira prévia ao litígio, ou mesmo após instaurada a litispendência.

Os negócios jurídicos processuais não constituem novidade no ordenamento jurídico pátrio, sendo possível observar a manifestação do instituto em diversos dispositivos do revogado Código de Processo Civil de 1973, havendo na doutrina quem aponte a existência de negócios processuais típicos na legislação desde as Ordenações Filipinas, passando pelo Regulamento 737/1850 e o Código de Processo Civil de 1939 (NOGUEIRA, 2020). Com o advento do Código de Processo Civil de 2015, no entanto, para além da manutenção de negócios jurídicos processuais típicos já identificados em legislações processuais pretéritas, ${ }^{8}$ estabeleceu-se previsão genérica para que as partes celebrem negócios jurídicos processuais atípicos, regrando por si próprias, no âmbito da autonomia da vontade, o objeto e os efeitos desejados com o ajuste.

Em outros termos, conforme leciona Rosa Maria de Andrade Nery (2015, p. 263) há agora verdadeira cláusula geral de autorregramento da vontade, permitindo às partes “[...] se conduzirem de forma mais livre durante o iter procedimental, por decorrência de algo a que se pode denominar autogerência parcial do processo", extraída a partir do caput do art. 190 do CPC/2015, nos seguintes termos:

Art. 190. Versando o processo sobre direitos que admitam autocomposição, é lícito às partes plenamente capazes estipular mudanças no procedimento para ajustá-lo às especificidades da causa e convencionar sobre os seus ônus, poderes, faculdades e deveres processuais, antes ou durante o processo.

O conteúdo do dispositivo indica de maneira precisa que os negócios jurídicos processuais

7 Forma autocompositiva em que as partes dialogam diretamente, podendo ou não ser assistidas por advogado. Rodrigo Mazzei e Bárbara Seccato Ruis Chagas (2018) enfrentam de maneira brilhante a temática do tratamento adequado de conflitos, sob a perspectiva de que o art. $5^{\circ}$, inciso XXV, da $\mathrm{CF} / 88$ demandaria não apenas a garantia de inafastabilidade da jurisdição, mas, sobretudo um tratamento adequado dos conflitos para que deles se extraia o melhor e mais efetivo resultado para a sociedade. A negociação, no atual cenário, apresenta-se como forma de tratamento de especial relevância, dadas as particularidades de incerteza jurídica e até mesmo de limitação dos serviços judiciários em função da pandemia da COVID-19, o que dificultaria o próprio desenvolvimento do iter procedimental em tempo razoável.

8 Daniel Amorim Assumpção Neves afirma (2018, p. 388), a respeito dos negócios jurídicos processuais típicos, que "[...] já no CPC/1973 existiam várias passagens que os consagravam de forma expressa". Ainda segundo a lição do autor, "Sempre que a lei prever um negócio jurídico processual de forma expressa, tem-se negócio jurídico processual típico". 
poderão versar sobre dois objetos distintos: I) situações processuais das partes e II) alterações no procedimento, destinadas a ajustá-lo às especificidades da causa (DIDIER JR., 2018, p. 25).

Fredie Didier Jr. (2018, p. 20) situa a possibilidade de celebração de negócios jurídicos processuais atípicos como decorrência do princípio do respeito ao autorregramento da vontade no processo, que “[...] visa, enfim, à obtenção de um ambiente processual em que o direito fundamental de autorregular-se possa ser exercido pelas partes sem restrições irrazoáveis ou injustificadas." Essa autonomia para a regulação de interesses resulta em verdadeiro repertório de poderes a serem exercidos pelos sujeitos de direito para o estabelecimento de situações jurídicas, desde que, obviamente, tal exercício se legitime nos limites do próprio ordenamento jurídico (NOGUEIRA, 2020).

Há inegável potencial na utilização de negócios jurídicos processuais atípicos para a modulação do procedimento, tornando-o melhor ajustado à lide e permitindo que o processo alcance com efetividade o seu escopo de pacificação social, em verdadeira expressão da instrumentalidade que lhe é imanente. $\mathrm{O}$ instituto propicia também um especial prestígio à dimensão do processo como procedimento em contraditório, garantindo-se às partes a efetiva oportunidade de participação na construção do caminho - iter procedimental - para a solução da contenda, em diálogo com o juiz, a quem caberá o controle das modificações procedimentais intentadas pelas partes e, nesta atividade, dados os contornos da garantia do contraditório, deverá levar em consideração os fundamentos por elas apresentados, inclusive enfrentando-os fundamentadamente no caso de recusa de aplicação do negócio processual (MADUREIRA, 2017).

No escopo aqui tratado, de repactuação das relações contratuais firmadas por partes empresárias diante dos efeitos da pandemia da COVID-19, desde já se valendo da possibilidade de autorregramento da vontade com efeitos em eventual processo judicial, a cooperação entre as partes se manifestará não apenas no plano material - como decorrência da boa-fé objetiva - mas também na seara processual, caracterizado por Nunes (2008) como ambiente policêntrico em que as partes e o juiz se correlacionam de forma participativa para a construção da decisão judicial.

Consideramos, assim, a situação ora vivenciada como oportunidade para que as empresas, dados os profundos impactos da pandemia nas atividades econômicas, possam se valer da cláusula geral de autorregramento da vontade para deliberar junto aos demais sujeitos do negócio a imediata ou futura - a depender da existência ou não de processo em curso - disposição de situações processuais ou realização de modificações procedimentais para harmonizar o processo às especificidades do litígio. Ocorre que muito embora os negócios jurídicos processuais atípicos constituam importante ferramenta de cooperação para a adequação do procedimento ao bem objeto de tutela jurisdicional, há considerável indefinição quanto aos limites objetivos dessas avenças, o que talvez explique a sua ainda tímida utilização no foro e rara previsão em instrumentos contratuais, questão que se tangencia no item seguinte.

\subsection{Considerações acerca do objeto das convenções processuais}

O que há de mais intrigante e ainda pouco definido quanto ao objeto dos negócios jurídicos 
processuais atípicos é questão da delimitação dos critérios mínimos a serem observados pelas partes em sua celebração, a fim de que suas cláusulas não afastem indevidamente as garantias fundamentais do processo ou criem hipóteses que venham a macular a própria sistematicidade da legislação processual.

Desde a promulgação do CPC/2015, e especialmente a partir de sua vigência, tornou-se mais abundante a elaboração trabalhos acadêmicos destinados à realização de uma abordagem científica dos negócios jurídicos processuais atípicos, analisando questões relativas a sua natureza, elementos e condições para que o objeto das avenças fosse reputado adequado às finalidades do instituto, indubitavelmente ligadas à noção de flexibilização procedimental para a prestação de uma tutela jurisdicional justa e efetiva.

Pode-se inferir, sem a necessidade de maiores investigações, que a disciplina das invalidades dos negócios jurídicos em geral se projetará para a análise de validade das convenções processuais, exigindo-se que sejam celebradas por agente capaz, possuam objeto lícito, possível determinado ou determinável, e forma prescrita ou não defesa em lei. ${ }^{9}$ Por conseguinte, as hipóteses de nulidade e anulabilidade dos negócios jurídicos em decorrência dos vícios de consentimento e de vícios sociais também se aplicarão aos ajustes de vontade voltados a produzir efeitos processuais, retirando-lhes a eficácia. Do parágrafo único ${ }^{10}$ do art. 190 do CPC/2015 extrai-se, outrossim, que a inserção abusiva de negócios jurídicos processuais atípicos em contratos de adesão ou a sua celebração por parte que se encontre em condições de manifesta vulnerabilidade serão parâmetros a inquinar a juridicidade do ato, caso constatados in concreto.

Tentando lançar premissas lógicas para a análise da questão, Daniel Amorim Assumpção Neves (2018) aduz, no que diz respeito às posições das partes processuais, que este tipo de convenção a elas se limita, não podendo versar sobre os poderes-deveres do juiz, a exemplo do dever de decisão fundamentada e de conformação à ratio decidendi dos precedentes formalmente vinculantes (art. 927, CPC/2015), por exemplo.

Cassio Scarpinella Bueno (2015, p. 189) afirma haver menos dificuldade em listar as hipóteses de convenções em tese possíveis do que em identificar os precisos limites do poder de autorregramento da vontade no processo, “[...] máxime quando, de acordo com o 'modelo constitucional do direito processual civil', as regras relativas ao procedimento são de competência dos Estados". Contudo, sinaliza o autor no sentido de não estar convencido a respeito de um alcance muito amplo do instituto que prevê a autogerência parcial do processo, assinalando que a natureza cogente de boa parte dos dispositivos processuais acabará por limitar substancialmente as hipóteses de customização do procedimento.

Compartilhando de visão semelhante, ao menos no que se refere à cogência das normas

9 A própria ideia subjacente ao art. 190 do CPC/2015 - atipicidade da negociação processual - denota que a forma das convenções será livre. Conjectura-se que dada a necessidade de precisa delimitação da modificação procedimental intentada pelos celebrantes, é provável que a maior parte das convenções processuais atípicas assumam a forma escrita. Nada obstante, reputa-se perfeitamente possível a celebração de negócios jurídicos pela forma oral, em audiência, por exemplo.

10 Parágrafo único. De ofício ou a requerimento, o juiz controlará a validade das convenções previstas neste artigo, recusando-lhes aplicação somente nos casos de nulidade ou de inserção abusiva em contrato de adesão ou em que alguma parte se encontre em manifesta situação de vulnerabilidade. 
processuais como um dos parâmetros a indicar o afastamento de determinadas estipulações levadas a efeito pelas partes, José Miguel Garcia Mediana e Moisés Casarotto (2018, p. 236) assentam que também as regras jurídicas materiais - em especial em matéria de invalidades - nortearão a atividade de controle judicial:

\begin{abstract}
Os negócios processuais esbarram nas regras cogentes processuais. Por conseguinte, o espaço de autonomia para autorregramento da vontade neste setor do ordenamento jurídico acaba sendo significativamente reduzido, embora, ao menos no direito brasileiro, exista. [...] Por outro lado, considerando que a regulamentação processual dos negócios processuais não é exaustiva, bem como pela própria natureza jurídica do acordo, é evidente que muitas normas de direito material são aplicáveis ao negócio processual, seja no plano da existência, seja no plano da validade ou mesmo no plano da eficácia.
\end{abstract}

Fredie Didier Jr. (2017, p. 430), por seu turno, admite a celebração de ajustes procedimentais ou sobre posições processuais das partes com a derrogação de normas cogentes, como as que fixam pressupostos processuais: "É possível acordo sobre pressupostos processuais. Não há incompatibilidade teórica entre negócio processual e pressuposto processual. Tudo dependerá do direito positivo". Nada obstante, para o autor (2018) há disposições processuais - v.g. as que preveem os recursos - que são de reserva legal, não se admitindo que sejam introduzidas ou modificadas pelas partes. De outra banda, Humberto Theodoro Jr. (2015) não admite a possibilidade de que negócios jurídicos processuais versem sobre pressupostos processuais ou condições da ação, tampouco sobre qualquer matéria de ordem pública.

Rosa Maria Andrade Nery (2015) consigna que o comando que se extrai do art. 190 do $\mathrm{CPC} / 2015$ permite às partes a negociação sobre matérias de ordem pública, ao contrário do que se possa imaginar a priori. Entretanto, sustenta a autora a impossibilidade de as partes negociarem temas alusivos a direitos fundamentais, a exemplo dos que tratam da jurisdição, juiz natural, duplo grau, ampla defesa e devido processo legal.

Em exposição sobre o tema Pedro Henrique Nogueira (2020, p. 285) institui que "As normas constitucionais do processo civil, inclusive os princípios, funcionam como limites objetivos aos negócios processuais e convenções sobre o processo e não se admite a prática de atos negociais que afastem suas prescrições". Prossegue o autor (pp. 285-286), afirmando que o objeto negocial deve ser reputado inválido caso se mostre incompatível com a natureza cogente de normas processuais infraconstitucionais.

Outras diretrizes também parecem nortear a atuação do magistrado no controle do autorregramento da vontade no processo, como I) os requisitos de negócios processuais típicos correlatos; II) os princípios da isonomia, boa-fé objetiva e da cooperação; III) custos decorrentes da alteração procedimental e IV) o núcleo de determinadas garantias fundamentais (DIDIER JR.; LIPIANI; ARAGAO 2018, pp. 43-45).

Assim, apesar da ausência de sistematização e de critérios precisos para a definição dos limites objetivos dos negócios jurídicos processuais atípicos, a natureza cogente de determinadas 
normas procedimentais, o núcleo dos direitos fundamentais que se projetam para o ambiente processual - v.g. o devido processo legal substancial - e a efetividade das alterações procedimentais para uma solução mais adequada do litígio se mostram como principais parâmetros limitativos da autogerência parcial do procedimento.

É nesse viés de utilização dos negócios jurídicos processuais atípicos nos contratos interempresariais para ajuste do procedimento às especificidades da causa e da situação excepcional ora vigente, com observância dos direitos e garantias fundamentais, buscando extrair das contendas relacionadas à COVID-19 o resultado mais efetivo possível, que se identifica ensejo para uma maior difusão e consolidação do instituto nas relações jurídicas.

\section{PECULIARIDADES DAS RELAÇÕES INTEREMPRESARIAIS E NEGOCIAÇÃO PROCESSUAL ATÍPICA}

Situada, pois, a importância da negociação processual atípica em um ambiente de profundas incertezas quanto ao regime legal a que se subsumirão os contratos e da exegese que lhes será conferida diante dos efeitos da pandemia do novo Coronavírus, como meio de tornar a tramitação de eventual - e provável - demanda judicial futura o mais eficiente, efetiva e afeiçoada às peculiaridades do litígio, objetiva-se explorar adiante a aplicabilidade do instituto no âmbito dos contratos interempresariais, assim denominados aqueles celebrados entre partes empresárias.

Antes de se adentrar, contudo, à análise pragmática da negociação processual atípica nas relações interempresariais, importa diferenciar os contratos de existenciais dos contratos de lucro, na medida em que o grau de autonomia que cada um exibe será determinante para que se avalie a extensão com que as partes poderão dispor de situações processuais por meio de convenções processuais atípicas. Essencial também investigar as notas características dos contratos celebrados entre partes empresárias, situações de que cuidam os subitens seguintes.

\subsection{Contratos existenciais $x$ contratos de lucro}

A dicotomia entre os contratos existenciais e contratos de lucro foi inicialmente proposta por Antônio Junqueira de Azevedo (2009) ${ }^{11}$ caracterizando-se aqueles por serem celebrados entre pessoas não empresárias e voltados à subsistência, enquanto estes são firmados entre empresários e possuem finalidade estritamente lucrativa. Em uma segunda oportunidade, Junqueira de Azevedo (2009, p. 600) revisitou suas proposições iniciais para se aprofundar nos critérios distintivos entre estas categorias, elucidando que a força obrigatória dos contratos, princípio clássico do direito contratual, se manifesta com maior intensidade nos contratos de lucro, nos quais o grau de disparidade entre as partes é menor ou inexistente:

11 Naquela oportunidade, bem pontuou o professor que "Digladiam-se, de um lado, os defensores da segurança jurídica, com os olhos voltados ao mundo empresarial, e, de outro, os defensores das pessoas físicas mal aquinhoadas economicamente, despreparadas para atuar num mercado sofisticado. A nosso ver, o direito brasileiro e, talvez, o direito universal, devesse, no séc. XXI, fazer uma distinção essencial, admitindo expressamente uma nova dicotomia contratual. Essa dicotomia seria a de contratos empresariais e de contratos existenciais". (AZEVEDO, 2009, p. 185). 
Os contratos existenciais têm basicamente como uma das partes ou ambas, as pessoas naturais; essas pessoas estão visando a sua subsistência. [...] Ora, as pessoas naturais não são "descartáveis" e os juízes têm que atender às suas necessidades fundamentais; é preciso respeitar o direito à vida, à integridade física, à saúde, à habitação etc. de forma que cláusulas contratuais que prejudiquem esses bens podem ser desconsideradas. Já os contratos de lucro são aqueles entre empresas ou entre profissionais e, inversamente, se essas entidades ou pessoas são incompetentes, devem ser expulsas, "descartadas", do mercado ou da vida profissional. No caso desses contratos de lucro, a interferência dos juízes perturba o funcionamento do mercado ou o exercício das profissões; o princípio pacta sunt servanda tem que ter aí maior força.

Basan (2016) esclarece se tratar de diferenciação hermenêutica fundada, em síntese, no aporte de novos princípios às relações contratuais a partir do Estado Social. É que a teoria contratualista clássica, erigida em paradigma liberal, voltava-se à valorização exacerbada do individualismo e da liberdade, sendo daí decorrentes os princípios basilares do direito contratual, como o pacta sunt servanda e o da autonomia da vontade. Com o desenvolvimento do Estado Social, no entanto, observou-se o surgimento de princípios corolários dos valores da dignidade da humana e do solidarismo, como os da boa-fé objetiva e função social dos contratos que, segundo Morsello (2018), se somaram aos princípios clássicos para compor o arcabouço principiológico do direito contratual, transformando profundamente o modo de análise e interpretação das avenças.

Consideramos que a dicotomia interpretativa proposta por Junqueira de Azevedo adquire maior nitidez a partir da vigência da Lei de Liberdade Econômica - Lei ${ }^{\circ} 13.874$, de 20 de setembro de 2019 - norteada por princípios que reforçam a autonomia dos contratos de lucro, entre eles os da garantia de liberdade e da intervenção subsidiária e excepcional do Estado sobre as atividades econômicas. ${ }^{12}$ A novel legislação previu critérios interpretativos para os negócios jurídicos, conferindo aos celebrantes a oportunidade para a livre pactuação de regras de interpretação e colmatação de lacunas diversas das legalmente fixadas ${ }^{13}$, além da possibilidade de instituição de parâmetros objetivos a nortearem a revisão e resolução dos contratos.

A Lei $n^{0} 13.874 / 2020$ introduz ainda disposições específicas atinentes aos contratos empresariais. Estabelece-se a presunção de que os negócios empresariais são paritários e simétricos, garantindo-se a aplicação do conteúdo negocial livremente estipulado, inclusive com derrogação de normas de direito empresarial que não ostentem natureza cogente. ${ }^{14}$ Todas essas disposições vão ao encontro da linha intelectiva proposta por Junqueira de Azevedo no sentido da prevalência da liberdade e da autonomia nos contratos de lucro.

Veja-se, então, que também na seara da negociação processual o maior ou menor grau de discrepância entre as posições dos contratantes repercutirá na análise e interpretação do acordo procedimental, sobretudo quando se constatar potencial prejuízo para a parte desfavorecida ou vulnerável. 
Em nosso sentir, é perfeitamente possível a celebração de convenções processuais atípicas em contratos existenciais, como os de consumo, de locação, trabalhista etc., desde que se verifique que à parte foi conferida a possibilidade de real deliberação específica acerca das cláusulas a se projetarem no processo, preferencialmente realizada em situação que atenue a vulnerabilidade p. ex. mitigação da vulnerabilidade jurídica por meio da assistência por advogado. Nos contratos interempresariais, a seu turno, dada a presunção de simetria e paridade entre as partes, reputamos que haverá ampla autonomia para a modificação convencional do procedimento e para a disposições de situações processuais.

Além da simetria entre as partes, outras notas distintivas indicam ser adequada a atribuição de ampla convencionalidade processual nos contratos interempresariais, conforme tratado adiante.

\subsection{Contratação entre empresas: outras notas distintivas}

Os contratos empresariais são aqueles celebrados entre partes que exerçam, profissionalmente, atividade econômica organizada para a produção ou a circulação de bens ou de serviços. Como via de regra, a contratação efetivada entre empresas busca propiciar as condições - insumos, serviços etc. - para que o exercício da atividade alcance resultados lucrativos.

De acordo com a classificação proposta por Antonio Junqueira de Azevedo, inserem-se na categoria dos contratos de lucro, desde que, obviamente, sejam celebrados pela empresa como parte dos processos relacionados à sua finalidade lucrativa. É que nem toda contratação efetuada por empresas será necessariamente atrelada à cadeia de atividades de propósito econômico, podendo ser celebrados contratos desvinculados do objeto social do empreendimento, ainda que entre as partes do negócio figurem apenas empresários.

A finalidade lucrativa inerente aos negócios jurídicos celebrados entre empresas, segundo Paula Forgioni (2010, p. 60), lhes confere um viés peculiar, e que condiciona, inclusive, a tomada de decisão do empresário por contratar ou não:

A empresa contrata porque entende que o negócio lhe trará mais vantagens do que desvantagens. As contratações são também resultado dos custos de suas escolhas; o agente econômico para obter a satisfação de sua necessidade, opta por aquela que entende ser a melhor alternativa disponível, ponderando os custos que deverá incorrer para a contratação de terceiros.

Ainda de acordo com Forgioni (2010), alguns fatores são preponderantes para que as negociações entre empresas se justifiquem do ponto de vista dos custos de transação, como o grau de confiabilidade no cumprimento da avença e a existência de um ambiente que propicie a segurança jurídica e a previsibilidade quanto aos efeitos decorrentes do contrato. Em uma análise de relação custo-benefício negocial, os agentes econômicos sopesam diversos fatores, entre eles a possibilidade de inadimplemento das estipulações contratuais, ante a impossibilidade de previsão integral das prováveis inconsistências a serem verificadas durante a execução da avença (GIANNAKOS, 2018). 
A existência de um ambiente negocial que privilegie o atendimento às expectativas das partes favorece o fluxo das relações econômicas (FORGIONI, 2010). Assim, pontua-se que no âmbito das relações interempresariais é necessário que o desenvolvimento das avenças ocorra precisamente conforme delineado em suas cláusulas, atingindo os resultados que legitimamente se espera delas, sob pena de desestímulo à circulação de bens e serviços.

Diante dessas características, verifica-se que nas negociações interempresariais a força obrigatória dos contratos assume especial relevância, tendo aí potencial de preponderância frente a outros princípios contratuais, o que se justifica não apenas pela necessidade de prestígio à confiança no cumprimento das tratativas, mas também porque, como visto em linhas acima, a negociação ocorrerá entre partes que ostentam condições mais homogêneas, não se verificando, a priori, a existência de vulnerabilidade. ${ }^{15}$

E, como tal, consideramos que nestes contratos o intervencionismo judicial sobre as negociações processuais atípicas também deva ser o mínimo possível, justificando-se apenas para afastar objetos negociais: I) ilícitos (p. ex. que resultem na ocorrência de fraude processual); II) que representem ofensa às garantias fundamentais do processo (afastamento negocial do contraditório, p. ex.) e III) que ensejem afronta às normas fundamentais do processo civil ou ao interesse público subjacente a determinadas normas processuais cogentes (seria o caso, p. ex., de um negócio jurídico processual atípico de modificação de competência absoluta).

Assim posta a questão, a amplitude negocial para a disposição de situações processuais ou ajuste de procedimento em contratos empresariais se mostra consideravelmente extensa, sendo possível se cogitar de uma série de formatações abstratamente possíveis para que se alcance o escopo previsto no art. 190 do CPC/2015, algumas analisadas com maior detença adiante.

\section{HIPÓTESES DE NEGÓCIOS JURÍDICOS PROCESSUAIS INTEREMPRESARIAIS PERTINENTES AO CONTEXTO DA PANDEMIA DA COVID-19}

Como visto, as notas características dos contratos interempresariais indicam serem estes ambientes propícios para a ampla disposição de situações jurídicas processuais ou previsão de desvios procedimentais. Contudo, diante dos estreitos limites do presente trabalho e das conclusões dantes expostas no sentido de que o atual contexto de pandemia pavimenta o caminho para um maior protagonismo da negociação processual atípica, examina-se adiante apenas hipóteses consideradas aptas a mitigar os impactos do cenário de crises econômica, de inadimplemento e de certeza jurídica retratados no item 2 supra.

\subsection{Procedimentos executivos}

Os procedimentos executivos seguramente se apresentam como um dos campos mais

15 Não se está aqui a repelir, em abstrato, a ocorrência de vulnerabilidade no âmbito das contratações entre empresas. Deveras, é possível que a empresa, em determinada contratação, se apresente em condição de vulnerabilidade econômica, técnica, jurídica etc. - perante a outra parte e, restando tal condição demonstrada na situação concreta, o paradigma de análise e intepretação do contrato tomará novas feições, mitigando-se a preponderância de princípios clássicos como o pacta sunt servanda. 
propícios tanto para a revisão de relações contratuais empresariais ainda não judicializadas - incluindo cláusulas de negociação pré-processuais - quanto para a celebração de avenças processuais em demandas já instauradas. No âmbito pré-processual, seria possível, diante do cenário da pandemia de COVID-19, revisitar contratos ou outros atos jurídicos que constituam ou resultem na formação de títulos executivos extrajudiciais para a estipulação de situações processuais que tornem eventual execução o mais satisfatória possível para o credor, resultando em menor sacrifício ao devedor. Na mesma esteira, demandas executivas já instauradas poderiam se tornar o palco para o desenvolvimento de convenções processuais destinadas a tornar o procedimento melhor ajustado às delicadas circunstâncias atualmente vigentes.

A doutrina aponta como vantagens da negociação processual atípica executiva o ganho de efetividade decorrente da remodelagem procedimental conforme o interesse dos litigantes, assim como o aumento de previsibilidade e diminuição dos riscos da execução. No campo dos negócios firmados entre partes empresárias, o ambiente de consensualidade propiciado pelas convenções processuais executivas estimula a celebração de futuras transações entre as partes, na medida em que cria as condições para que a execução atinja satisfatoriamente o interesse do exequente, sem com que isto importe em sacrifício demasiado do executado (DIDIER JR.; CABRAL, 2018).

Dentre as hipóteses de ajuste de vontade direcionadas a produzir efeitos em procedimentos executivos pertinentes no atual contexto, destaca-se a possibilidade de celebração de pactum de non exequendo - ou pacto de não execução -, de maneira pré-processual, submetido a termo ou condição. Trata-se de pacto em que o credor se compromete a não executar - ou iniciar a fase de cumprimento de sentença - enquanto não sobrevier a implementação do termo ou condição indicados no conteúdo do negócio, podendo ser unilateral, se resultar em obrigações unicamente para o credor, ou bilateral, na hipótese de o pacto de não execução envolver contraprestação do devedor. ${ }^{16}$ Em sendo a execução norteada pelo princípio da disponibilidade e guiada pelo interesse do exequente, não se vislumbra óbice à celebração de negócio processual limitando a deflagração do procedimento, sobretudo porque poderia o credor, independentemente de convenção, decidir por ajuizar a demanda executiva somente em momento mais oportuno.

Desse modo, poder-se-ia cogitar, por exemplo, de inserção, em contratos de interempresariais, de negócio jurídico pré-processual ${ }^{17}$ prevendo pactum de non exequendo submetido à condição suspensiva de retomada do crescimento dos indicadores econômicos ou da saúde financeira da empresa. Outra hipótese pertinente no atual momento seria a inclusão de pacto de não execução vinculado a termo, protraindo a deflagração de eventual execução. A nosso ver, estas representam possibilidades de negócios jurídicos processuais que certamente impulsionariam

16 A contraprestação poderá se dar no próprio negócio em que inserido o pacto de não execução ou até em futuras avenças. O credor pode, por exemplo, aceitar o pacto de não execução submetido a termo ou condição, desde que o devedor renuncie a determinada cláusula que lhe favoreça no próprio contrato ou que se comprometa a dar preferência ao credor em futuras negociações.

17 Embora exista posicionamento de que o pacto de não execução possui natureza material, importando em renúncia do direito objeto do litígio, entendemos que a natureza material só terá lugar quando ocorrer disposição total e irrestrita da execução. No mesmo sentido, Fredie Didier Jr. e Antonio do Passo Cabral (2018, p. 146): "É que a convenção de não executar pode subsistir sem que signifique uma renúncia no plano do direito material: a parte pode abrir mão da via executiva resguardando-se outras modalidades menos invasivas de cobrança do crédito, como a ação monitória, e, ainda, a possibilidade de usar o crédito como um contradireito, como no caso da compensação". 
a manutenção das relações contratuais - e, por conseguinte, da atividade econômica - durante a pandemia da COVID-19, haja vista a previsibilidade que proporcionam ao devedor quanto ao não ajuizamento, por ora, de demanda executiva por parte do credor.

Pela perspectiva do cumprimento de sentença, admite-se como apropriado ao presente contexto a pactuação para não se dar início ao cumprimento provisório, pelas mesmas razões expostas quanto à execução e se admite também a modulação da eficácia da avença mediante termo ou condição.

Há ainda a possibilidade de utilização das convenções processuais em contratos empresariais para tornar as medidas constritivas e executivas menos gravosas ao executado, sem descuidar da satisfação do interesse do credor/exequente (art. 797, CPC/2015). Uma importante ferramenta neste sentido seria a escolha prévia do objeto da penhora, abrindo-se mão desde já da constrição prioritária em dinheiro (art. $\left.835, \S 1^{\circ}, \mathrm{CPC} / 2015\right)$ para concentrá-la em outro bem que não venha a afetar o fluxo de caixa da empresa. No mesmo sentido, seria possível fixar previamente, via negociação processual, o método expropriatório de que se valerá o exequente, situação que embora dispense a realização de acordo, poderá atribuir maior previsibilidade ao desfecho do procedimento executivo (NOGUEIRA, 2020).

Pode-se outrossim obter profícuos resultados na execução a partir da combinação da negociação processual atípica com a importação de técnicas executivas provenientes de outros procedimentos, para aplicá-las em substituição à técnica padrão. Rodrigo Reis Mazzei e Tiago Figueiredo Gonçalves (2020) examinam de forma certeira a possibilidade de o processo de execução e do cumprimento de sentença atuarem como válvulas para o transporte de técnicas processuais, a partir de uma exegese destinada a conferir ao art. 771 do CPC/2015 o seu potencial máximo de realização. Esse transporte de técnicas seria possível inclusive em caráter substitutivo da técnica prioritária, desde que a substituta se mostre mais eficiente. ${ }^{18}$ Citam os autores, nesse escopo, a aplicação do art. 867 do CPC/2015, que prevê a penhora de frutos e rendimentos de coisa móvel ou imóvel, como método prioritário satisfação do crédito, em lugar de se percorrer o iter das formas expropriatórias típicas, desde que a alteração resulte em ganho de eficiência.

Assim, para que se tenha maior previsibilidade - elemento essencial nas transações interempresariais -, pode-se estabelecer, via negociação processual, a preponderância da técnica prevista no art. 867 como meio satisfativo do crédito, evitando-se a penhora em dinheiro ou de outros ativos da empresa, já tão comprometidos diante dos efeitos da pandemia do novo Coronavírus. Evita-se, também, a submissão do executado aos métodos - nem sempre eficientes de expropriação convencionais.

\subsection{Pacto de instância única e redefinições na sistemática dos prazos processuais}

Sabe-se que os custos decorrentes da litigância, a depender da hipótese, podem ser bastante elevados para as empresas. Longos períodos de tramitação e o desdobramento da relação

$\overline{18 \text { Sustentam os }}$ professores que as técnicas poderão ser importadas/exportadas, inclusive, de e para procedimentos especiais do próprio código e de legislações especiais ou estatutárias, tamanho potencial participativo do CPC/2015 (MAZZEI; GONÇALVES, 2020, p. 32-34). 
processual em recursos ou ações autônomas impugnativas elevam sobremaneira o dispêndio das partes, sobretudo quando se está em jogo a tutela de bens e interesses de elevado valor econômico. Nesta senda, como forma de abreviar a solução da contenda e, por conseguinte, mitigar o consumo de recursos financeiros das empresas ${ }^{19}$ - questão extremamente sensível no presente cenário -, admite-se como viável a celebração de convenção processual de instância única.

A medida consiste na pactuação de renúncia prévia ao direito de recorrer do provimento jurisdicional que vier a resolver o litígio. Em função da incidência do princípio da voluntariedade recursal, a opção por recorrer ou não se insere no âmbito de livre disposição da parte sendo, portanto, passível previsão em negócio jurídico pré-processual (DIDIER JR.; LIPIANI; ARAGAO, 2018)

Em complemento ao escopo de otimização da tramitação processual, coloca-se a possibilidade de convenção acerca da redução ou até mesmo supressão dos prazos para as postulações e manifestações das partes, tais como a apresentação de contestação e réplica (NOGUEIRA, 2020). Não se entrevê óbice, outrossim, para a instituição negocial de que a contagem dos prazos em dias seja realizada levando-se em conta os dias corridos, afastando-se a aplicação do método previsto no art. 219 do CPC/2015.

Nada obstante, mesmo com as redefinições acima propostas, em razão dos altos índices de morosidade verificados no Poder Judiciário brasileiro, é pouco provável que eventual demanda instaurada neste momento venha a ser solucionada ainda durante o contexto de pandemia, de maneira a que a redução de despesas afetas à litigância repercuta em maior disponibilidade financeira para superação das atuais adversidades em melhores condições.

\subsection{Convenção de conciliação ou mediação prévia obrigatória}

Como discutido no item 2, os efeitos da pandemia da COVID-19 sobre as relações jurídicas e o relativo grau de insegurança jurídica quanto ao regime jurídico a que se subsumirão os contratos impulsionarão a revisitação dos negócios jurídicos cuja execução se encontra em curso, a fim de que as partes negociem solução consensual, podendo até mesmo aditar a avença para incluir cláusulas com eficácia em eventual relação processual instaurada futuramente.

Não apenas na hipótese de renegociação de negócios em curso, mas sobretudo nos contratos interempresariais a serem celebrados no atual contexto, é possível que as empresas ajustem a obrigatoriedade de submissão de eventual litígio à tentativa de conciliação ou mediação prévia, o que favorece a possibilidade de solução célere, eficaz e menos custosa da demanda. Não entendemos que acordos de tal natureza representem ofensa à garantia constitucional de acesso à justiça prevista no art. $5^{\circ}$, inciso XXXV, da CRFB/88, havendo apenas condicionamento 19 Benjamin Tabak e José de Lima Ramos Pereira (2019, p. 47), ao analisarem a teoria econômica da litigância, expõem que “[...] as pessoas são racionais e possuem um olhar para o futuro, considerando os custos e os benefícios existentes na demanda, ou seja, o objetivo de quem irá discutir judicialmente uma ameaça ou um direito violado reside na otimização do seu bem-estar, empregando os meios disponíveis para o alcance dos seus objetivos com o menor desperdício de recurso possível". 
autoatribuído da apreciação meritória enquanto não submetida a causa à tentativa de solução consensual.

Ainda que se repute a limitação negocial aqui discutida como potencialmente ofensiva aos ditames do art. $5^{\circ}$, inciso XXXV, CRFB/1988 - matéria sobre a qual não se aprofunda aqui, dados os estreitos limites do trabalho - o fato é que a conciliação ou mediação obrigatória podem coexistir com a apreciação jurisdicional da lide, ainda que de forma parcial.

Verifica-se o surgimento de diversas plataformas digitais de conciliação e mediação, algumas destas implementadas por Tribunais e até mesmo pelo próprio Conselho Nacional de Justiça, ${ }^{20}$ disponibilizando ambiente para que as partes possam negociar os termos do conflito e solucioná-lo consensualmente. Em ambientes tais, a negociação pode ocorrer em paralelo à distribuição judicial da demanda, ficando resguardado inclusive a apreciação de tutelas provisórias. Melhor dizendo, a parte já acessou o Poder Judiciário - o que, se sabe, não representa o núcleo essencial da garantia de acesso à justiça -, nada obstante o integral acesso à ordem jurídica justa fique condicionado a uma tentativa prévia de negociação.

No ponto, deve-se ter em mente que o CPC/20 alçou ao status de norma fundamental a necessidade de que o Estado promova, sempre que possível, a solução consensual dos conflitos. ${ }^{21}$ Da leitura do CPC/2015 e da própria exposição de motivos do Projeto de Lei que lhe deu ensejo, infere-se a clara opção legislativa pela atribuição de ênfase no tratamento adequado dos conflitos, o que reforça a compreensão no sentido da legitimidade das convenções processuais que condicionam a plena apreciação jurisdicional à tentativa prévia de resolução autocompositiva.

\section{CONCLUSÃO}

O contexto de insegurança jurídica e de crise de adimplemento instaurado como decorrência da pandemia da COVID-19 tem ensejado a necessidade de aproximação dos contratantes para negociação e reconfiguração dos negócios às circunstâncias ora operantes. O cenário se mostra especialmente impactante nas relações interempresariais, em função do volume de transações e a dos expressivos valores que normalmente ostentam essas contratações. Nessa perspectiva de revisão de cláusulas contratuais e até mesmo de maior cautela em relação às estipulações a serem lançados em futuros contratos, podem se valer as empresas dos negócios jurídicos processuais como meio para garantir maior previsibilidade e adequabilidade do procedimento às circunstâncias do caso e características essenciais das partes envolvidas.

Em regra, as contratações promovidas entre empresas se instauram em ambiente de homogeneidade de posições entre as partes e de não observância de vulnerabilidade presumida, o que induz o reconhecimento de maior autonomia na disposição de situações jurídicas e a 20 Plataforma Mediação Digital do CNJ. Nada obstante o termo "mediação" a ferramenta é voltada à negociação entre as partes. Disponível em https://www.cnj.jus.br/mediacaodigital/. Acesso em 08 jun. 2020.

21 Art. $1^{\circ}$. [...] $\S 2^{\circ} \mathrm{O}$ Estado promoverá, sempre que possível, a solução consensual dos conflitos. 
necessidade de se atribuir força obrigatória ao que restar convencionado. O mesmo se observa na seara da negociação processual atípica em contratos de tal natureza, os quais somente poderão ser afastados em caso de objeto ilícito ou que atente contra o núcleo das garantias fundamentais do processo. Assim, o quadro de disposição de situações processuais e alterações procedimentais nos contratos interempresariais se apresenta bastante amplo, sendo possível conjecturar hipóteses variadas de negócios jurídicos processuais abstratamente legítimos e úteis para o alcance dos objetivos previstos no art. 190 do CPC/2015.

Guardando pertinência com quadro vigente de efeitos da pandemia da COVID-19, identifica-se que os procedimentos executivos são campos férteis para a inserção de cláusulas a projetarem efeitos processuais, tornando possível a satisfação do exequente sem onerar demasiadamente o executado em momento de tamanhas adversidades. Verifica-se proficuidade, outrossim, na modulação procedimental destinada a encurtar a tramitação processual e, com isso, os custos dela decorrentes, o que se alcançaria via pactuação de instância única e reformulação da sistemática dos prazos processuais. Apresenta-se como válida ainda a celebração de negócio jurídico processual direcionado a impedir o desenvolvimento de demanda judicial enquanto não intentada solução consensual prévia do litígio, o que também pode ocasionar a redução de despesas afetas à litigância.

Com o regular desenvolvimento das relações contratuais durante a pandemia, naturalmente as empresas se verão diante de situações ainda não cogitadas de negociação processual atípica que sejam apropriadas a tornar eventual litígio decorrente da execução de contratos interempresariais mais eficiente e apropriada às peculiaridades do ramo, a serem objeto de futuras investigações acadêmicas na tentativa de se formular quadros genéricos de negociabilidade com pertinência mesmo após o decurso dos efeitos do novo Coronavírus sobre as relações jurídicas.

\section{REFERÊNCIAS}

AZEVEDO, Antônio Junqueira de. Novos estudos e pareceres de direito privado. São Paulo: Saraiva, 2009.

BASAN, Arthur Pinheiro. O contrato existencial: análise de decisão judicial que assegura a sua aplicação. Revista Brasileira de Direito Civil, Rio de Janeiro, v. 7, n. 1, p. 9-32, jan./mar. 2016.

BRASIL. Conselho Nacional de Justiça. Plataforma Mediação Digital. Disponível em: https:// www.cnj.jus.br/mediacaodigital/. Acesso em 8 jun. 2020.

BRASIL. Lei n. 10.406, de 10 de janeiro de 2002. Institui o Código Civil. Disponível em: http://www.planalto.gov.br/ccivil_03/leis/2002/110406.htm. Acesso em 10 mai. 2020.

BRASIL. Lei n. 13.105, de 16 de março de 2015. Código de Processo Civil. Brasília, DF. Disponível em: http://www.planalto.gov.br/ccivil_03/_ato2015-2018/2015/lei/113105.htm. Acesso em 10 mai. 2020.

BRASIL. Lei n. 13.874, de 20 de setembro de 2019. Institui a Declaração de Direitos de 
Liberdade Econômica; estabelece garantias de livre mercado. Disponível em: http://www. planalto.gov.br/ccivil_03/_ato2019-2022/2019/1ei/L13874.htm. Acesso em 10 mai. 2020.

BRASIL. Lei n. 14.010, de 10 de junho de 2020. Dispõe sobre o Regime Jurídico Emergencial e Transitório das relações jurídicas de Direito Privado (RJET) no período da pandemia do coronavírus (Covid-19). Disponível em: http://www.planalto.gov.br/ccivil_03/_ato20192022/2020/lei/L14010.htm. Acesso em 14 jun. 2020.

BUENO, Cassio Scarpinella. Manual de direito processual civil. São Paulo: Saraiva, 2015.

COUTURE, Eduardo Juan. Fundamentos del derecho procesal civil. 3. ed. Buenos Aires: Depalma, 1958.

DIDIER JR., Fredie. Curso de direito processual civil. v. 1. 19. ed. Salvador: Juspodivm, 2017.

DIDIER JR., Fredie. Ensaios sobre os negócios jurídicos processuais. Salvador: Juspodivm, 2018.

DIDIER JR., Fredie; CABRAL, Antonio do Passo. Negócios jurídicos processuais atípicos e execução. Revista do Ministério Público do Rio de Janeiro, Rio de Janeiro, n. 67, p. 137-165, jan./mar. 2018.

DIDIER JR., Fredie; LIPIANI, Júlia; ARAGAO, Leandro Santos. Negócios jurídicos processuais em contratos empresariais. Revista de Processo, São Paulo, v. 279, p. 41-66, mai. 2018.

DWORKIN, Ronald. Levando os direitos a sério. 2. ed. São Paulo: Martins Fontes, 2007.

FORGIONI, Paula Andrea. Teoria geral dos contratos empresariais. São Paulo: Editora Revista dos Tribunais, 2010.

GIANNAKOS, Demétrio Beck da Silva. Análise econômica dos negócios jurídicos processuais. Revista de Processo, São Paulo, v. 278, p. 497-519, abr. 2018.

MADUREIRA, Claudio. Fundamentos do novo processo civil brasileiro: o processo civil do formalismo valorativo. Belo Horizonte: Fórum, 2017.

MARQUES, Claudia Lima. Exceção dilatória para os consumidores frente à força maior da pandemia de Covid-19: pela urgente aprovação do PL 3.515/2015 de atualização do CDC e por uma moratória aos consumidores. Revista de Direito do Consumidor, São Paulo, v. 129, p. 0123, mai./jun. 2020.

MAZZEI, Rodrigo; CHAGAS, Bárbara Seccato Ruis. Métodos ou tratamento adequados dos conflitos? Revista Jurídica da Escola Superior de Advocacia da OAB-PR, Curitiba, a. 3, n. 1, p. 323-350, mai. 2018.

MAZZEI, Rodrigo; GONÇALVES, Tiago Figueiredo. Ensaio sobre o processo de execução e o cumprimento da sentença como bases de importação e exportação no transporte de técnicas processuais. In: ASSIS, Araken de; BRUSCHI, Gilberto Gomes (coord.). Processo de execução e cumprimento de sentença: temas atuais e controvertidos. São Paulo: Revista dos Tribunais, 2020 . 
MEDINA, José Miguel Garcia; CASAROTTO, Moisés. O novo código de processo civil e negócios jurídicos processuais no âmbito do Ministério Público. Revista dos Tribunais, São Paulo, v. 107, n. 988, p. 233-250, fev. 2018.

MORSELLO, Marco Fábio. Análise categorial dos contratos existenciais e de lucro. In: GUERRA, Alexandre Dartanhan de Mello. (coord). Estudos em homenagem a Clóvis Beviláqua por ocasião do centenário do direito civil codificado no Brasil. v. 2. São Paulo: Escola Paulista da Magistratura, 2018.

NERY, Rosa Maria de Andrade. Fatos processuais. Atos jurídicos processuais simples. Negócio jurídico processual (unilateral e bilateral). Transação. Revista de Direito Privado, São Paulo, v. 16. n. 64, p. 263-264, out./dez. 2015.

NERY JUNIOR, Nelson. NERY, Rosa Maria de Andrade. Código civil comentado. 13. ed. rev., atual e ampl. São Paulo: Editora Revista dos Tribunais, 2019.

NEVES, Daniel Amorim Assumpção. Manual de direito processual civil. 8. ed. Salvador: Juspodivm, 2018.

NOGUEIRA, Pedro Henrique. Negócios jurídicos processuais. 4. Ed. Salvador: Juspodivm, 2020.

NUNES, Dierle José Coelho. Teoria do processo contemporâneo: por um processualismo constitucional democrático. Revista da Faculdade de Direito do Sul de Minas, Pouso Alegre, v. especial, p. 13-29, 2008.

SCHREIBER, Anderson. Manual de direito civil contemporâneo. São Paulo: Saraiva, 2018. TABAK, Benjamin Miranda; PEREIRA, José de Lima Ramos. Análise econômica do processo. Revista do Programa de Pós-graduação em Direito da UFC, Fortaleza, v. 39, n. 2, p. 39-60, jan./jul. 2019.

TARTUCE, Flávio. Manual de direito civil. 4. ed. rev., atual. e ampl. São Paulo: MÉTODO, 2014.

TEPEDINO, Gustavo. Crise financeira mundial, teoria da imprevisão e onerosidade excessiva. Soluções Práticas de Direito. Pareceres. v. 2. São Paulo: Revista dos Tribunais, 2012.

THEODORO JR., Humberto. Curso de direito processual civil. v. 1. 56. ed. rev. atual. e ampl. Rio de Janeiro: Forense, 2015.

World Health Organization. WHO Director-General's opening remarks at the media briefing on COVID-19 - 11 March 2020. Disponível em: https://www.who.int/dg/speeches/detail/whodirector-general-s-opening-remarks-at-the-media-briefing-on-covid-19---11-march-2020. Acesso em 29 abr. 2020.

Como citar: BUFULIN, Augusto Passamani. VILARINHO, Tiago Aguiar. Negócios jurídicos processuais atípicos em contratos interempresariais e a pandemia da covid 19. Scientia Iuris, Londrina, v. 24, n. 3, p. 10-30, nov. 2020. DOI: 10.5433/2178-8189.2020v24n3p10. ISSN: 2178- 
8189.

Recebido em: 18/06/2020

Aprovado em: 09/09/2020 